\title{
Atmospheric Carbon Dioxide and Nitrogen Oxides Emissions Data for 2003-2005 Model Year Trucks
}

\author{
Madhava R. Madireddy, Nigel N. Clark \\ Center for Alternative Fuels, Engines and Emissions, Department of Mechanical and Aerospace Engineering, \\ West Virginia University, Morgantown, West Virginia, USA \\ Email: madireddy1@gmail.com
}

Received 5 May 2015; accepted 28 August 2015; published 1 September 2015

Copyright (C) 2015 by authors and Scientific Research Publishing Inc.

This work is licensed under the Creative Commons Attribution International License (CC BY). http://creativecommons.org/licenses/by/4.0/

c) (i) Open Access

\begin{abstract}
Heavy-duty trucks account for a substantial portion of the atmospheric carbon dioxide $\left(\mathrm{CO}_{2}\right)$ and nitrogen oxides $\left(\mathrm{NO}_{\mathrm{x}}\right)$ inventory. The data presented in this paper will help the research community be interested in developing models that predict the $\mathrm{NO}_{\mathrm{x}}$ and $\mathrm{CO}_{2}$ levels in real use. Continuous data of emissions were recorded from chassis dynamometer testing of five 2003-2005 model year (MY) heavy-duty trucks. The instantaneous emissions rate was plotted against axle power in all cases. The effect of vehicle test weight and the drive cycle employed on the relation between emissions rate (grams per sec) and axle power was studied. The $\mathrm{NO}_{\mathrm{x}} / \mathrm{CO}_{2}$ ratio was found to be independent of the test cycle. The average $\mathrm{NO}_{\mathrm{x}} / \mathrm{CO}_{2}$ ratio for the 2003-2005 MY trucks was found to be 0.0051 , which agrees reasonably well with the estimated ratio of 0.0048 , based on certification standards. The data were compared to those from 1994-2002 MY trucks; the average $\mathrm{NO}_{\mathrm{x}} / \mathrm{CO}_{2}$ ratio for those trucks was 0.0141. For the 2003-2005 MY trucks, the distance specific $\mathrm{NO}_{\mathrm{x}}$ (grams per mile) and the fuel economy (miles per gallon) were less than those of 1994-2002 MY trucks.
\end{abstract}

\section{Keywords}

Emissions Inventory, Chassis Dynamometer, Instantaneous Emissions, $\mathrm{NO}_{\mathrm{x}} / \mathrm{CO}_{2}$ Ratio, Certification

\section{Introduction}

The purpose of this paper is to provide $\mathrm{NO}_{\mathrm{x}}$ and $\mathrm{CO}_{2}$ emissions data from the 2003-2005 model year (MY) heavy-duty trucks. The 2003-2005 trucks are still widely in service in the United States and do not have either 
diesel particulate filters (which became common after US 2007 regulations) or selective catalytic reduction (which was adopted only since the 2010 regulations). Some may favor using these older trucks in service because they are simpler in controls. The average vehicle miles travelled (VMT) by heavy duty trucks (defined as heavier than 26,000 lb) that are older than 5 years is more than $40 \%$ of the total VMT by all the heavy duty trucks according to the recently released Vehicle Inventory and Use Survey (VIUS) data [1]. The 2003-2005 MY trucks are about 7 - 9 years old and these trucks contribute about a sixth of the total VMT by all heavy duty trucks in the US. However, the emissions contribution from these trucks will be disproportionate to their VMT contribution due to the new stringent regulations. For example, these older trucks have $\mathrm{NO}_{\mathrm{x}}$ emissions about 10 times that of the new trucks due to new regulations. Hence, they contribute to total $\mathrm{NO}_{\mathrm{x}}$ emissions at about 3 times that of the new trucks.

Though heavy-duty diesel vehicles comprise only $2 \%$ of the on-road vehicle population by count, they operate for long hours at high loads. A study indicated that almost half of the on-road emissions of $\mathrm{NO}_{\mathrm{x}}$ were from heavy-duty diesel vehicles [2]. In 2000, Yanowitz et al. [3] argued that over the last two decades, the emissions of particulate matter (PM) from heavy-duty diesel engines had decreased, but $\mathrm{NO}_{\mathrm{x}}$ emissions had not. The EPA $\mathrm{NO}_{\mathrm{x}}$ emissions standard for $1994 \mathrm{MY}$ heavy-duty diesel engine was $5.0 \mathrm{~g} / \mathrm{bhp}$-hr and was $4.0 \mathrm{~g} / \mathrm{bhp}$-hr for 1998 MY engines. For $2004 \mathrm{MY}$ engines, the limiting value of $\mathrm{NO}_{\mathrm{x}}$ (including non-methane hydrocarbons) for certification was $2.4 \mathrm{~g} / \mathrm{bhp}-\mathrm{hr}$. Since the $\mathrm{NO}_{\mathrm{x}}$ standard in the US dropped substantially in 2004 and Not-To-Exceed (NTE) regulations were espoused, a reduction of $\mathrm{NO}_{\mathrm{x}}$ has been observed during chassis dynamometer testing [4]. This decrease came after the United States Environmental Protection Agency (USEPA), the United States Department of Justice, CARB and engine manufacturers (Caterpillar, Cummins, Detroit Diesel, Volvo, Mack Trucks, Renault and Navistar) reached a settlement [5] in October of 1998 to limit $\mathrm{NO}_{\mathrm{x}}$ emissions from heavyduty diesel engines. In December 2000, the EPA introduced new emission standards for MY 2007 and later heavy-duty engines [6].

In 1999, Ramamurthy and Clark [7] discussed the contribution that heavy-duty vehicle emissions make to the atmospheric $\mathrm{NO}_{\mathrm{x}}$ levels for 1994-1999 MY trucks. This paper attempts to extend that work by providing emissions data found for typical 2003-2005 MY heavy-duty trucks by analyzing the data in a manner similar to the one followed in reference [7], and to compare some of the interesting data with those of 1994-2002 MY trucks.

\section{Available Data}

The data used in this paper were obtained from chassis testing on five heavy-duty trucks from the E-55/59 program [8]-[10], which was jointly sponsored by the Coordinating Research Council (CRC), CARB, USEPA, Department of Energy (DOE), Office of Freedom CAR and Vehicle Technologies, National Renewable Energy Laboratory (NREL), South Coast Air Quality Management District and Engine Manufacturers Association. Data were obtained from the chassis dynamometer testing at the West Virginia University Transportable Heavy-Duty Vehicle Emissions Testing Laboratories (TRANS-LAB). A comprehensive explanation of the experimental procedures can be found in prior papers [11]-[13]. A brief description of the experimental set up is as follows. The dynamometer was a platform with flywheels, power absorbers and rollers. The vehicle was mounted on a test bed with the drive wheels on rollers. The rear wheels were allowed to rotate freely on the rollers. The power was absorbed from the vehicle wheel hubs by the power absorbers mounted on either side of the chassis bed, simulating the load on the vehicle. The power absorbers simulated real-world driving conditions by accounting for the aerodynamic and the frictional load. The flywheels were connected to the vehicle hubs and the vehicle load was established using a coast down procedure on the dynamometer. The torque produced by the vehicle was translated to the sensors through shafts and gear boxes. Sum of the readings of the sensors on either side should be equivalent to the axle torque. The vehicle was driven to follow the speed-time trace of the desired drive cycle. The target speed was provided on the computer screen to the driver while the test was running and the vehicle was driven to meet that speed which simulates the drive cycle used. The emissions were measured with exhaust gas analyzers and a data acquisition system. The losses associated with the tire-roller interaction have been discussed elsewhere [14].

\section{Vehicles Tested on the Chassis Dynamometer}

The data that were used in this analysis were from trucks identified as CRC-34, CRC-38, CRC-39, CRC-40, and CRC-63 in reference [8]. Two of these trucks, CRC-34 and CRC-40, had engines manufactured by Detroit Di- 
esel, and two others, CRC-38 and CRC-39, had engines manufactured by Cummins and the other truck had a Caterpillar engine. The first four engines were equipped with a cooled EGR to reduce the emissions of $\mathrm{NO}_{\mathrm{x}}$ [15]-[18]. EGR was proven most effective in reducing $\mathrm{NO}_{\mathrm{x}}$ at high loads of engine operation [19]. The vehicles were loaded on the dynamometer at three test weights of 30,000,56,000, and 66,000 lb. The specifications of the trucks are presented in the Table 1 . The odometer readings suggest that the engine and the emissions control systems would be in good working order.

\section{Drive Cycles Used for the Chassis Dynamometer Data}

The drive cycles suitable for trucks and buses for chassis dynamometer testing have been presented previously [20]. The data used in this analysis arose from E-55/59 chassis testing that was performed on the Urban Dynamometer Driving Schedule (UDDS) and the Heavy Heavy-Duty Diesel Truck (HHDDT) drive schedule [8]. The UDDS is a seventeen minute cycle with a peak speed of $60 \mathrm{mph}$ and is representative of the heavy-duty driving in US urban conditions. The development and examination of HHDDT schedule was presented elsewhere [21] [22]. The HHDDT schedule consists of five modes (Idle, Creep, Transient, Cruise and High-speed cruise). The creep mode represents very low speed truck operation with a maximum speed of $8.24 \mathrm{mph}$. The transient mode of HHDDT is a ten-minute drive that mimics the vehicle stopping and going at an average speed of $20 \mathrm{mph}$. It involves sharp accelerations and decelerations with a peak speed of less than $50 \mathrm{mph}$. The cruise mode of HHDDT cycle, which is representative of truck driving on the interstate, is a 2000 second cycle with constant peak speed of approximately $60 \mathrm{mph}$ for about 1400 seconds. The high-speed cruise mode is represented by HHDDT_S. It has an average speed of $50 \mathrm{mph}$ and a maximum speed of $67 \mathrm{mph}$ and it represents expressway truck driving. The speed time traces of all the cycles have been provided elsewhere [20] [21].

\section{Time-Alignment of Emissions with Axle Power}

The transient emissions data acquired [8] have a time delay associated with them relative to the speed and load history on the engine. The time delay between the power and emissions data is mainly due to the time taken for the exhaust to travel to the analyzers and the response time of the analyzers. To account for the delay in emissions measurement, the data from reference [8] were time-shifted with respect to power, which was considered (as a simplification) to be the single engine variable that influenced emissions production. The power and the measured emissions mass rate were time-aligned using the cross correlation technique, which has been presented earlier elsewhere [23]-[26].

\section{Dispersion of Axle Power}

Apart from time delay, emissions data can also be dispersed over a period of time when measured by the analyzer, i.e. the specific operating condition experienced by the engine may be sudden or momentary, but the measured response can be dispersed in time with the measured amplitude of a peak or a valley of emissions mass rate smaller than the peak actually produced by the engine at the manifold. Hence, the emissions data reported by the analyzers could be substantially different from the instantaneous emissions at the tailpipe. The reconstruction of the instantaneous emission signal from the continuous measured emissions involved numerical computations. The reverse transform process has several constraints and is prone to numerical instabilities [27]

\begin{tabular}{|c|c|c|c|c|c|}
\hline $\begin{array}{l}\text { Vehicle } \\
\text { Identity }\end{array}$ & Engine & $\begin{array}{l}\text { Engine hp \& } \\
\text { Displacement }\end{array}$ & $\begin{array}{c}\text { Vehicle } \\
\text { Model } \\
\text { Year }\end{array}$ & $\begin{array}{c}\text { Odometer } \\
\text { Reading } \\
\text { (miles) }\end{array}$ & $\begin{array}{c}\text { Test } \\
\text { Weights (lb) }\end{array}$ \\
\hline CRC-34 & DDC Series 60 & 500 hp \& 12.7 liters & 2004 & 19,094 & $30,000,56,000$ and 66,000 \\
\hline CRC-38 & Cummins ISX & 530 hp \& 15 liters & 2004 & 2829 & $30,000,56,000$ and 66,000 \\
\hline CRC-39 & Cummins ISX & 530 hp \& 15 liters & 2004 & 45 & 56,000 \\
\hline CRC-40 & DDC Series 60 & 500 hp \& 14 liters & 2004 & 8916 & 56,000 \\
\hline CRC-63 & Cat $3406 \mathrm{E}$ & 475 hp \& 15.1 liters & 2005 & 2731 & 56,000 \\
\hline
\end{tabular}


[28]. Hence the dispersion of the emission data was simulated by dispersing the axle power according to the dispersion function which was obtained in a manner similar to the one proposed by Ramamurthy and Clark [29] [30]. Separate dispersion functions were used for $\mathrm{NO}_{\mathbf{x}}$ and $\mathrm{CO}_{2}$. An instantaneous pulse of $\mathrm{NO}_{\mathrm{x}}\left(\right.$ or $\left.\mathrm{CO}_{2}\right)$ was injected into the dilution tunnel and the analyzer generated an impulse response (dispersion function) that corresponded to $\mathrm{NO}_{\mathrm{x}}$ (or $\mathrm{CO}_{2}$ ) data. A more elaborate description of the test set up and the procedure followed to obtain dispersion functions has been presented by the authors in their other studies [28] [31]. Since the emissions measured by the analyzer are dispersed, when they are compared against power, the power needs to be dispersed to negate the effect of emissions dispersion. Even though "dispersed axle power" does not have any physical significance, it can account for the dispersion associated with the emissions data if the emissions data vary. The effects of dispersion can be obtained by simply time dispersing the axle power as shown in Figure 1. It shall be noted from the figure that the correlation between the time-shifted $\mathrm{CO}_{2}$ and dispersed axle power $\left(\mathrm{R}^{2}\right.$ of 0.86) was found to be better than the correlation between the time-shifted $\mathrm{CO}_{2}$ and un-dispersed axle power ( $\mathrm{R}^{2}$ of 0.79 ). In both of the above cases, the data were time-aligned first.

\section{Emissions Data}

Second-by-second continuous data of two consecutive transient mode runs on CRC-40 loaded at 56,000 lb were presented (Figure 2). The results affirmed the run to run consistency by showing similar trends of emission mass flow rate against the dispersed axle power. The data scatter arose in this plot because the same power may be delivered to the axle with different combinations of engine torque and speed. More complex engine controls for the 2003-2005 MY trucks blurred the relationship between fuel consumption and axle power over the whole operating envelope relative to the earlier model year trucks discussed in reference [7]. Data might also have scatter because of imperfections in time-alignment and variations in dispersion. As shown in Figure 2, the emission rates for three different trucks on the HHDDT_S showed similar trends. In Figure 2 and Figure 3, the few high values of $\mathrm{CO}_{2}$ corresponded to high acceleration on some of the peaks of the HHDDT_S. The reader is cautioned not to interpret the intercept at zero power as low idle emissions. This is because the intercept is based on range of data and type of fit (quadratic, cubic or exponential). Moreover, $\mathrm{CO}_{2}$ emissions will be higher at the beginning of any acceleration period (the moment when the vehicle is accelerated) when the power is nearly zero. This is because the instantaneous emissions at the start of acceleration signify a finite value in the $\mathrm{CO}_{2}$ emissions when the power is still not transmitted to the axle. For these reasons, the carbon dioxide emissions at zero power were over-estimated and hence the intercepts did not fall within the range of idle emissions data [32] obtained from the trucks in the E-55/59 program.

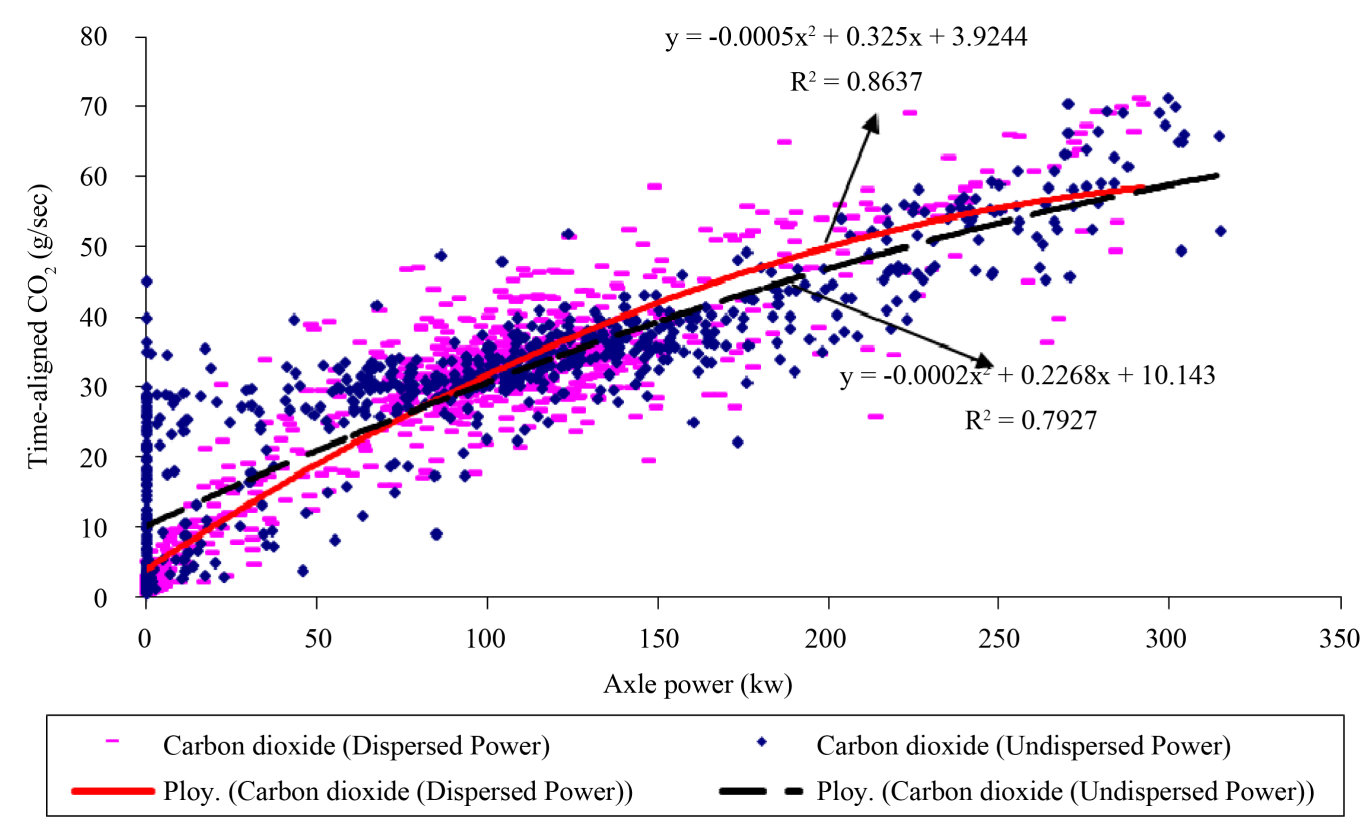

Figure 1. The effect of dispersion on the correlation between mass emissions rate and axle power. 


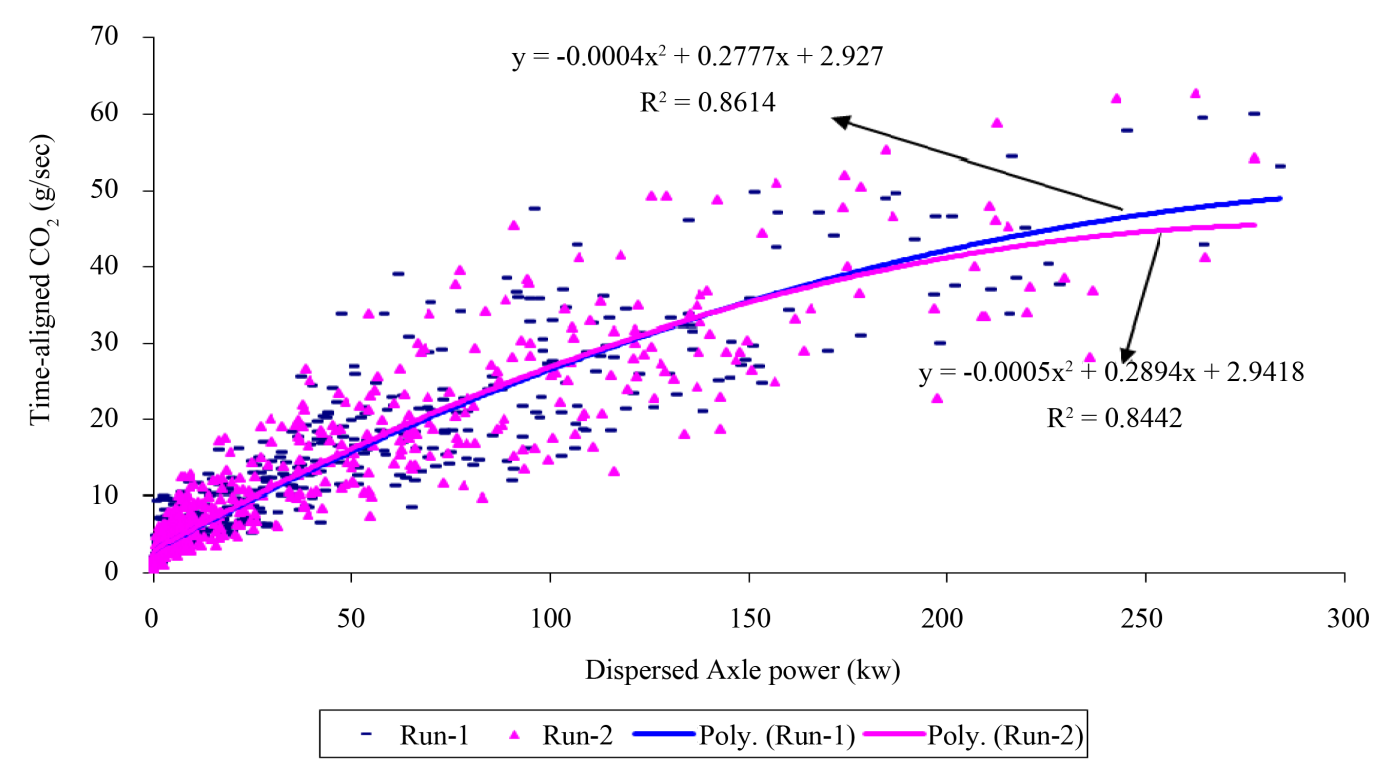

Figure 2. $\mathrm{CO}_{2}$ mass emissions rate for two consecutive runs tested on the HHDDT_S.

While $\mathrm{CO}_{2}$ correlated well $\left(\mathrm{R}^{2}\right.$ of 0.86$)$ with dispersed axle power, $\mathrm{NO}_{\mathrm{x}}$ did not $\left(\mathrm{R}^{2}\right.$ of 0.53$)$. This is because the $\mathrm{CO}_{2}$ was representative of the fuel consumed by the vehicle, and hence it correlated well with power, but the linear dependence of $\mathrm{NO}_{\mathrm{x}}$ on power was affected by the $\mathrm{NO}_{\mathrm{x}}$ control methods such as cooled EGR and retardation of fuel injection timing. The engines with EGR also employed variable geometry turbochargers (VGT) [33]-[35]. These technologies employed multi-dimensional control that affected the linear dependence of $\mathrm{NO}_{\mathrm{x}}$ on power. The increasing complexity of engine controls suggests that $\mathrm{NO}_{\mathrm{x}}$ may not be well correlated with power for recent $\mathrm{MY}$ vehicles, whereas $\mathrm{NO}_{\mathrm{x}}$ correlations with power were good for most older trucks [7]. For five vehicles tested on Central Business District (CBD) cycle and WVU 5-peak test cycle, $\mathrm{NO}_{\mathrm{x}}$ mass rate had showed a good correlation with power (with an average $\mathrm{R}^{2}$ of about 0.85 ) [7].

Cycle-specific emissions from heavy-duty vehicles were examined as well. Figure 4(a) shows the $\mathrm{CO}_{2}$ emissions rate from CRC-34 loaded at 56,000 lb and tested on cycles. Since all cycles do not utilize the vehicle's power output capability similarly, emissions rates at the same axle power vary from cycle to cycle. However, differences in the emissions rate curves were not substantial. Even if a single best fit line were used for the data from all the three drive cycles, the $\mathrm{R}^{2}$ values for each of the cycles would not vary even by $5 \%$ from those in Figure 4(a). The apparent deviation in the curves in Figure 4(b) in the 200 - $280 \mathrm{kw}$ power range is merely an effect of curve fitting to the data. For linear fits, the curves show negligible deviation from one another (Figure 4(c)). In fact, the lines representing the transient mode of HHDDT_S and the UDDS had exactly same slopes and almost the same intercepts and hence the lines overlapped.

To understand the effect of test weight on cycle emissions mass rate $(\mathrm{g} / \mathrm{s})$, data were considered from CRC-34 loaded at three different weights: 30,000, 56,000 and 66,000 lb and tested on the HHDDT_S. Emissions mass rates of $\mathrm{CO}_{2}$ and $\mathrm{NO}_{\mathrm{x}}$ as a function of dispersed axle power are shown in Figure 5 . The best fits of the three curves have similar slopes and intercepts. This suggests that the test weight does not significantly affect the $\mathrm{CO}_{2}$ and $\mathrm{NO}_{\mathrm{x}}$ power-specific emissions mass rates from the engine.

\section{Comparison with Old Truck Data}

The 2003-2005 MY truck emissions data were compared to the emissions data from 1994-2002 MY trucks. These data were also obtained from the E-55/59 study [8]. The emissions data were collected from twelve 1994-2002 MY trucks. These trucks were loaded at 56,000 lb and were driven through the HHDDT drive cycle.

The averages from transient cycle for the 1994-2002 MY trucks were compared with the corresponding averages from the transient mode of HHDDT schedule of the 2003-2005 MY trucks. The comparison is shown in Figure 6(a). In Figure 6, the trucks are grouped based on their vehicle MY so that the reader could appreciate the emission trends across model years. The truck-to-truck standard deviations are represented by the error bars. 


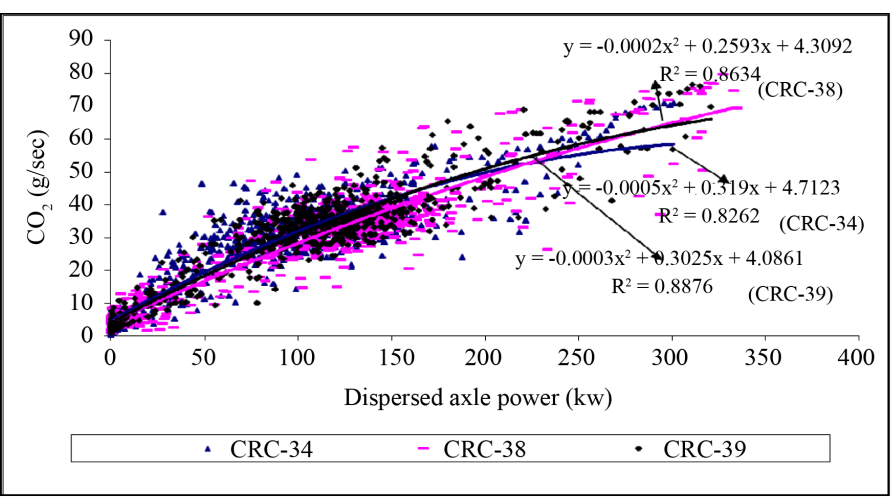

(a)

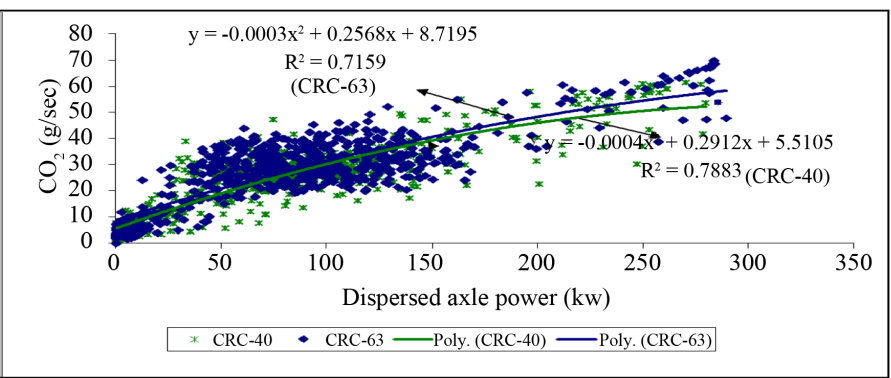

(b)

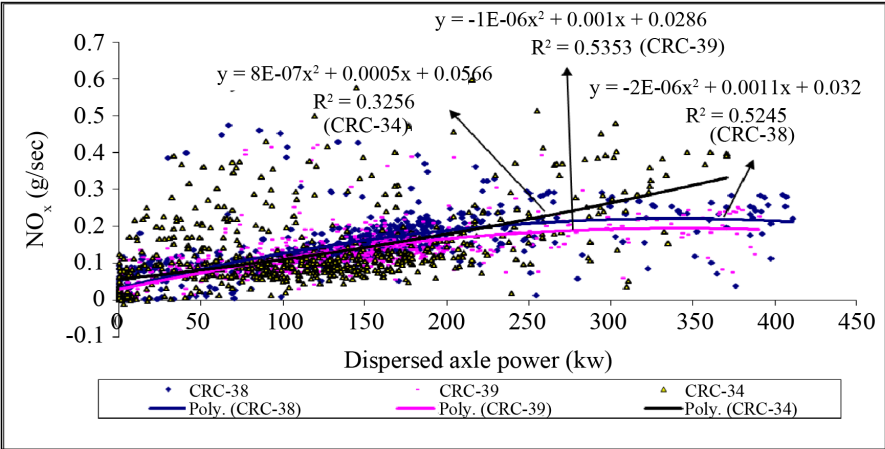

(c)

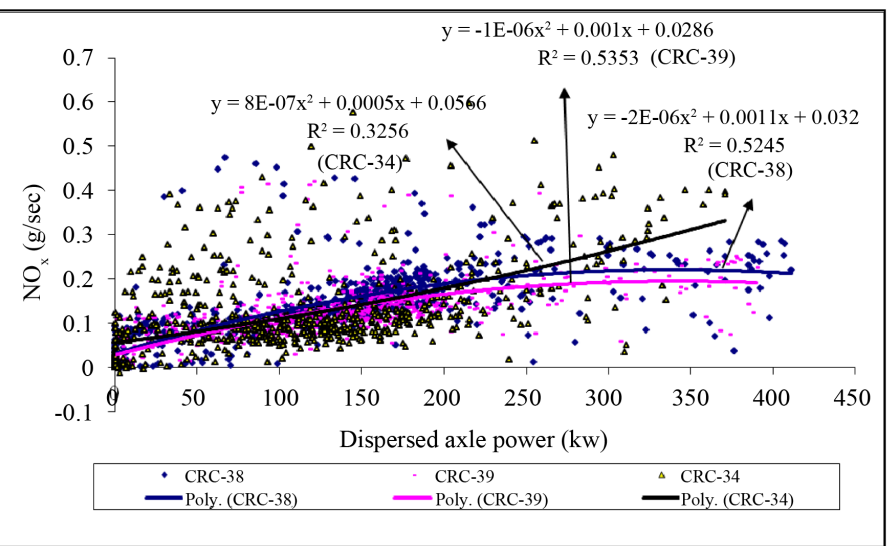

(d)

Figure 3. Mass emissions rate for five 2003-2005 MY trucks loaded at 56,000 lb and tested on the HHDDT_S. (a) (b) $\mathrm{CO}_{2}$; (c) (d) $\mathrm{NO}_{\mathrm{x}}$. 


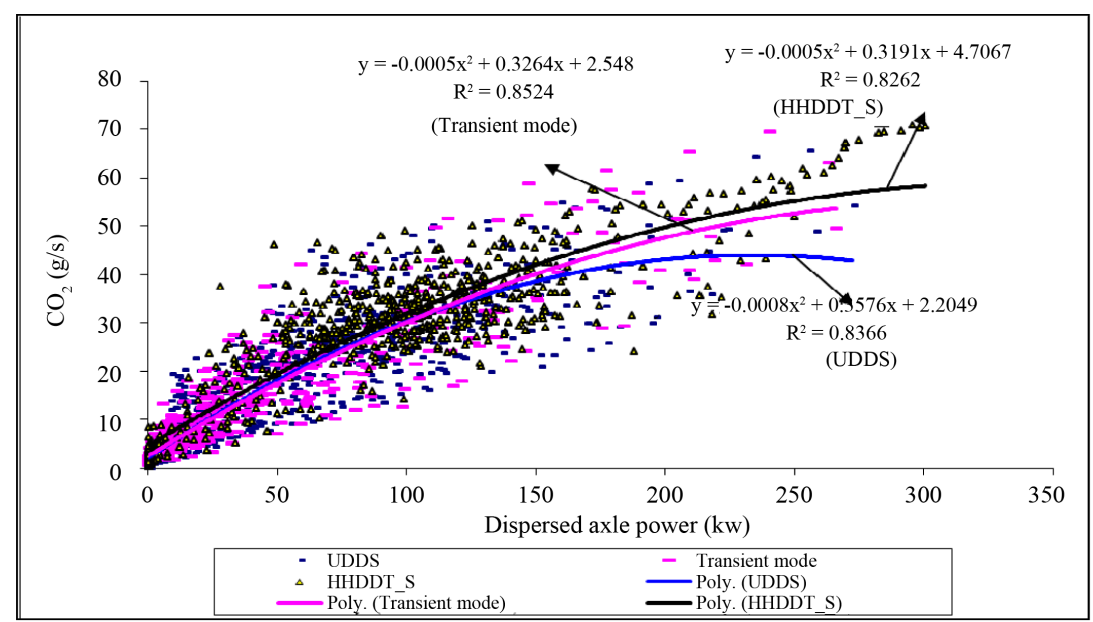

(a)

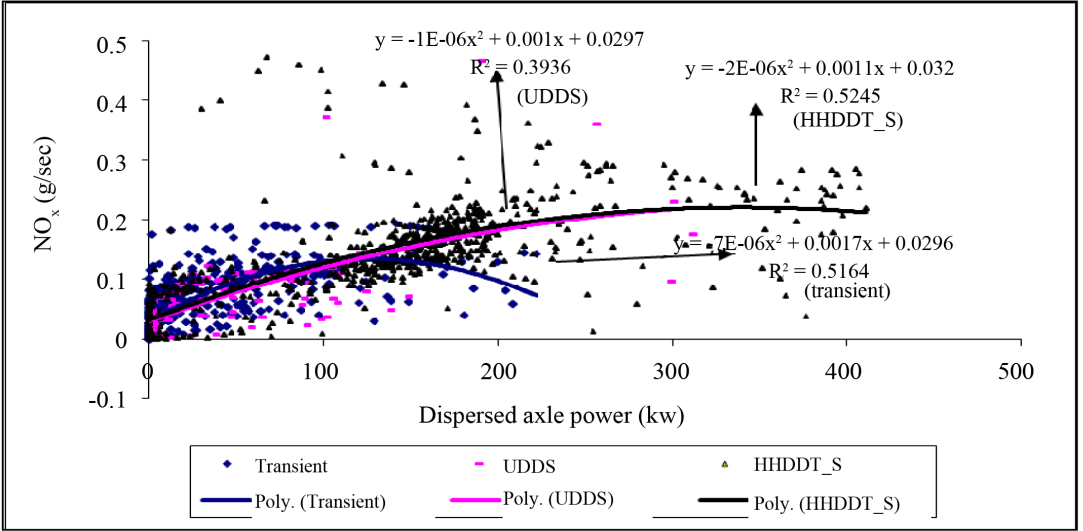

(b)

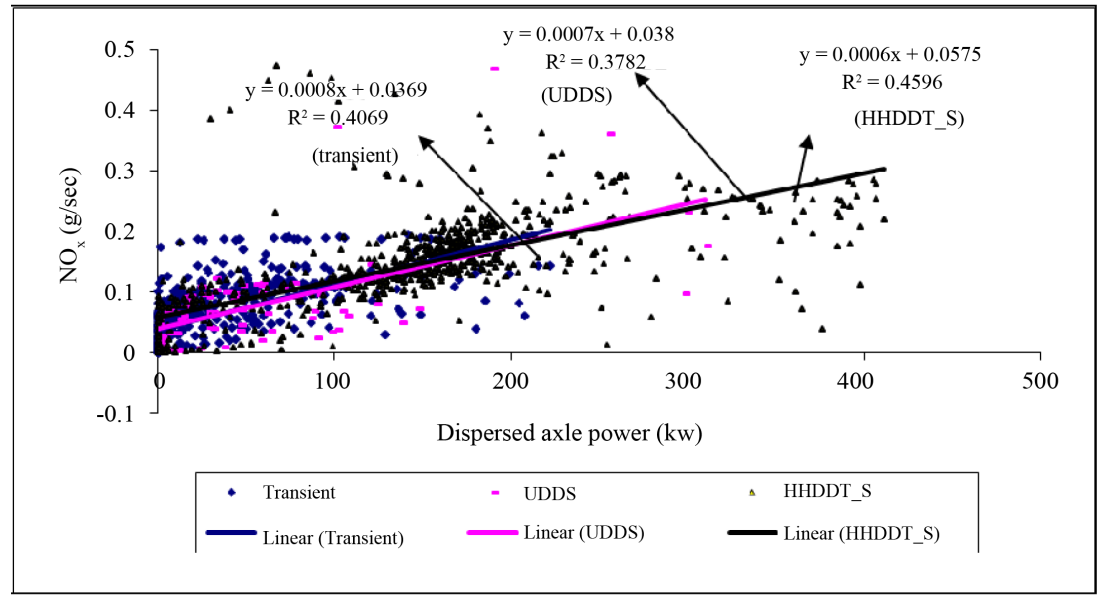

(c)

Figure 4. Mass emissions rate for CRC-34 (MY 2004) loaded at 56,000 lb and tested on three different cycles. (a) $\mathrm{CO}_{2}$; (b) $\mathrm{NO}_{\mathrm{x}}$; (c) $\mathrm{NO}_{\mathrm{x}}$ (with linear curve-fit).

The comparison of the averages based on the HHDDT_S is also shown in Figure 6(b). $\mathrm{NO}_{\mathrm{x}}$ emissions showed reduction both in grams per cycle and grams per mile. The time rate of emissions ( $\mathrm{g} / \mathrm{min}$ ), fuel economy (miles per gallon) and the distance specific emissions (g/mile) in transient and high-speed cruise were compared with those from the earlier MY trucks. When compared to the 1994-1998 MY trucks, the 2003-2005 MY trucks 


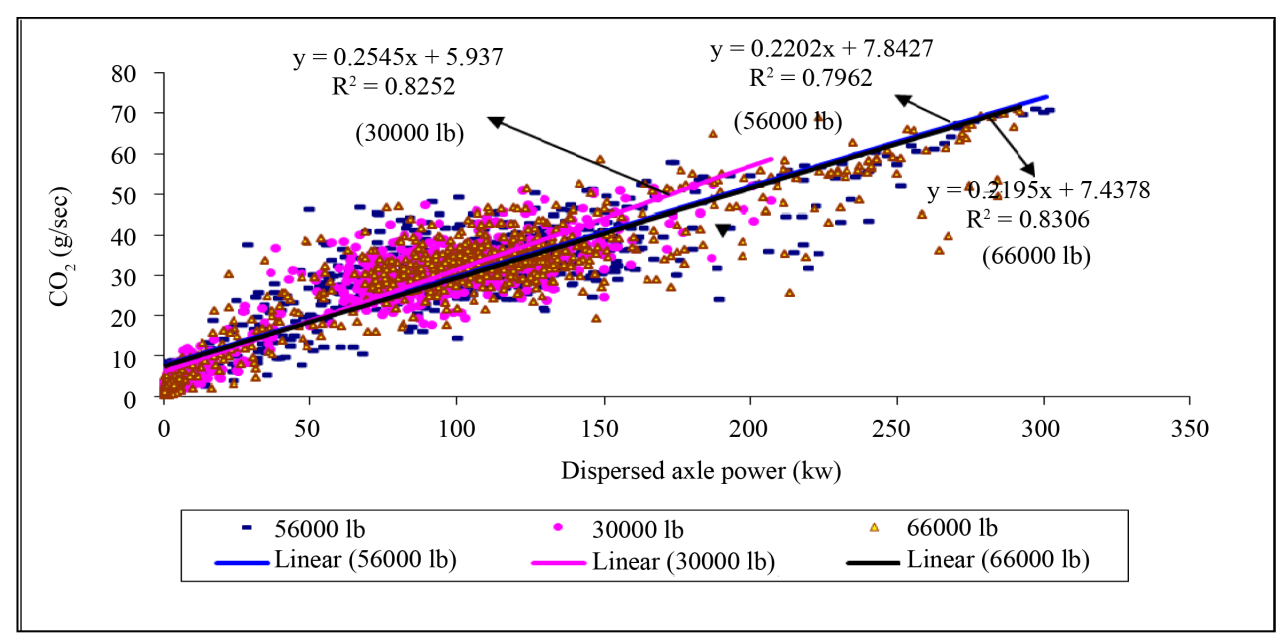

(a)

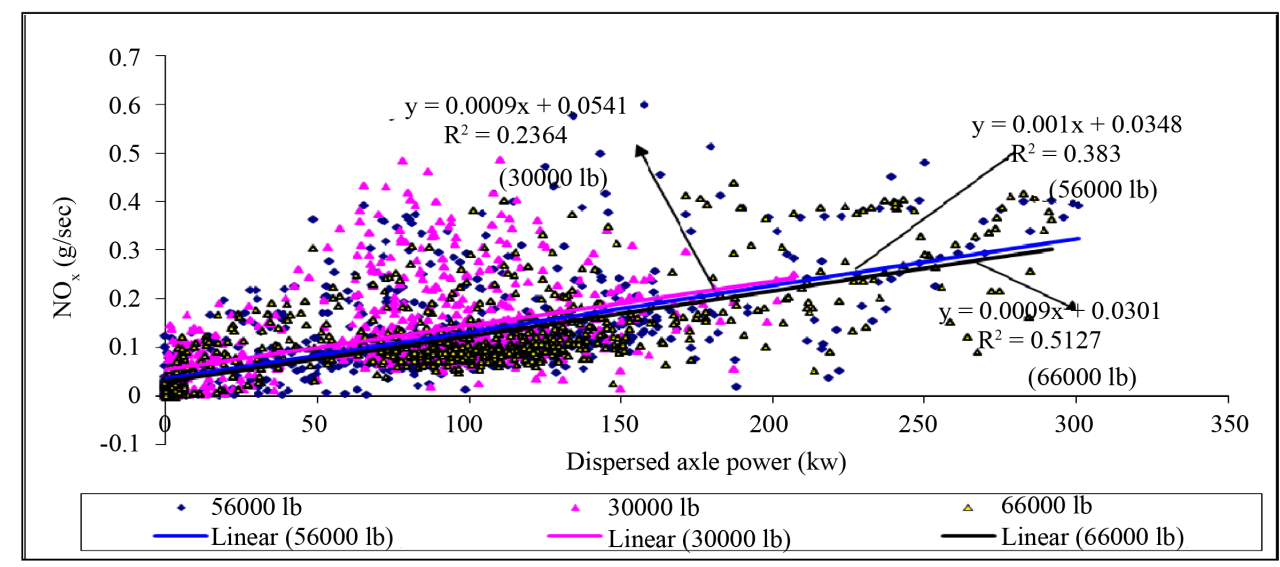

(b)

Figure 5. Mass emissions rates for CRC-34 (MY 2004) loaded at three different test weights and tested on the HHDDT_S. (a) $\mathrm{CO}_{2}$; (b) $\mathrm{NO}_{\mathrm{x}}$.

showed a decrease of about $40 \%$ in distance specific emissions. Note that the certification level for $\mathrm{NO}_{\mathrm{x}}$ has dropped about 40\% from $4 \mathrm{~g} / \mathrm{bhp}$-hr for the $1998 \mathrm{MY}$ heavy-duty engines to $2.4 \mathrm{~g} / \mathrm{bhp}$-hr for the 2004 and later MY heavy-duty vehicles.

\section{9. $\mathrm{NO}_{\mathrm{x}} / \mathrm{CO}_{2}$ Ratio}

$\mathrm{NO}_{\mathrm{x}} / \mathrm{CO}_{2}$ ratio can be useful in representing the emissions as a mass fraction of the burnt fuel. It differs from brake-specific $\mathrm{NO}_{\mathrm{x}}$ because it takes into account the reduced engine efficiency during low power operation. Figure 7 presents the data from CRC-34 loaded at 56,000 lb and tested on three different cycles. Figure 8 represents the data from the five trucks (described in Table 1 and from reference [8]) loaded at 56,000 lb and tested on THE HHDDT_S cycle. In both of these plots, the data did not follow a trend. This suggests that the ratio is independent of the test cycle and the vehicle. The ratio was found to be higher at lower axle power because of the advanced injection timing at idle and lighter loads. The average value of the ratio for the 2003-2005 MY trucks was 0.0051 . The corresponding ratio for all of the vehicles considered in the earlier study [7] by Ramamurthy and Clark was 0.0141 . This decrease of the ratio could be attributed to the more stringent standards and $\mathrm{NO}_{\mathrm{x}}$ reduction technologies after October 2002 (The 2004 standards were brought forward to October 2002 under the Consent Decree). For 2004 and later MY engines, the limiting average value of $\mathrm{NO}_{\mathrm{x}}$ (including non methane hydrocarbons) for transient FTP is $2.4 \mathrm{~g} / \mathrm{bhp}-\mathrm{hr}$. It should be noted that the transient FTP certification considers only the cycle average, but it does not put a limit on the peak emissions in the cycle. In other words, at 


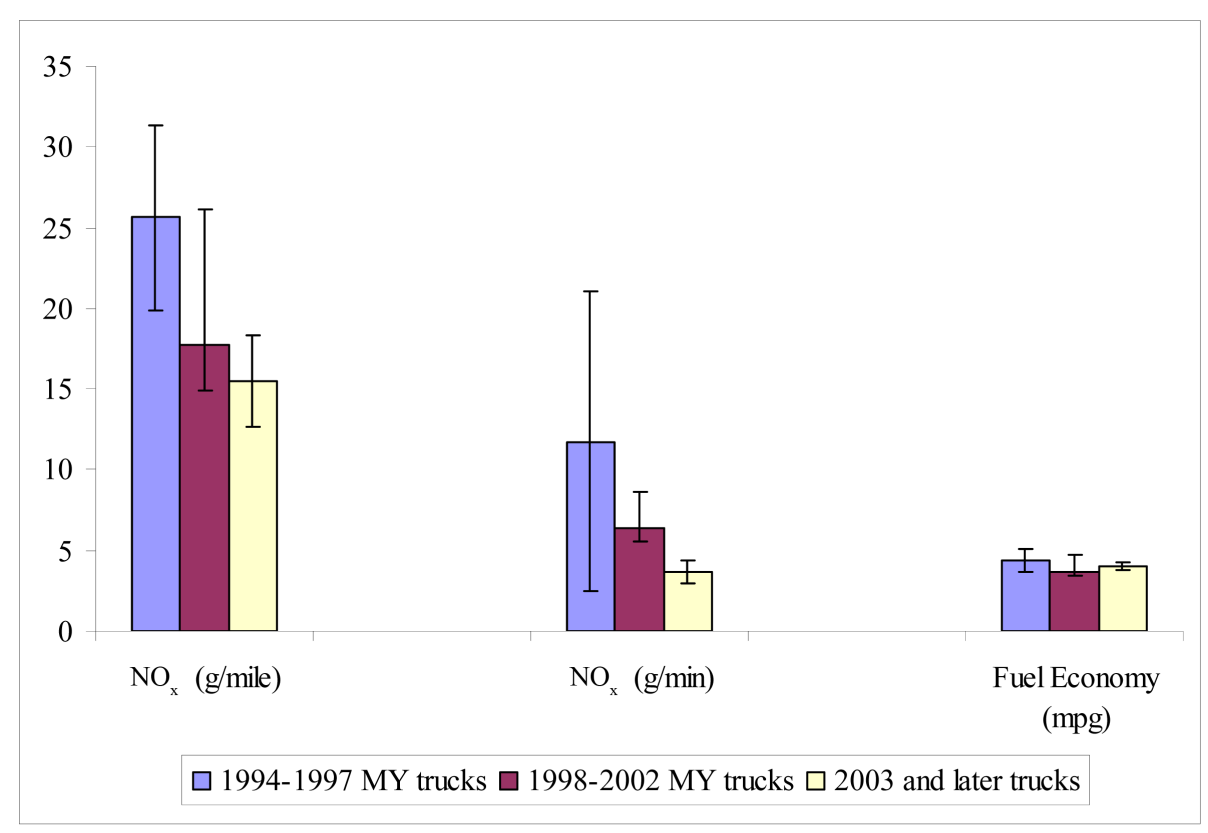

(a)

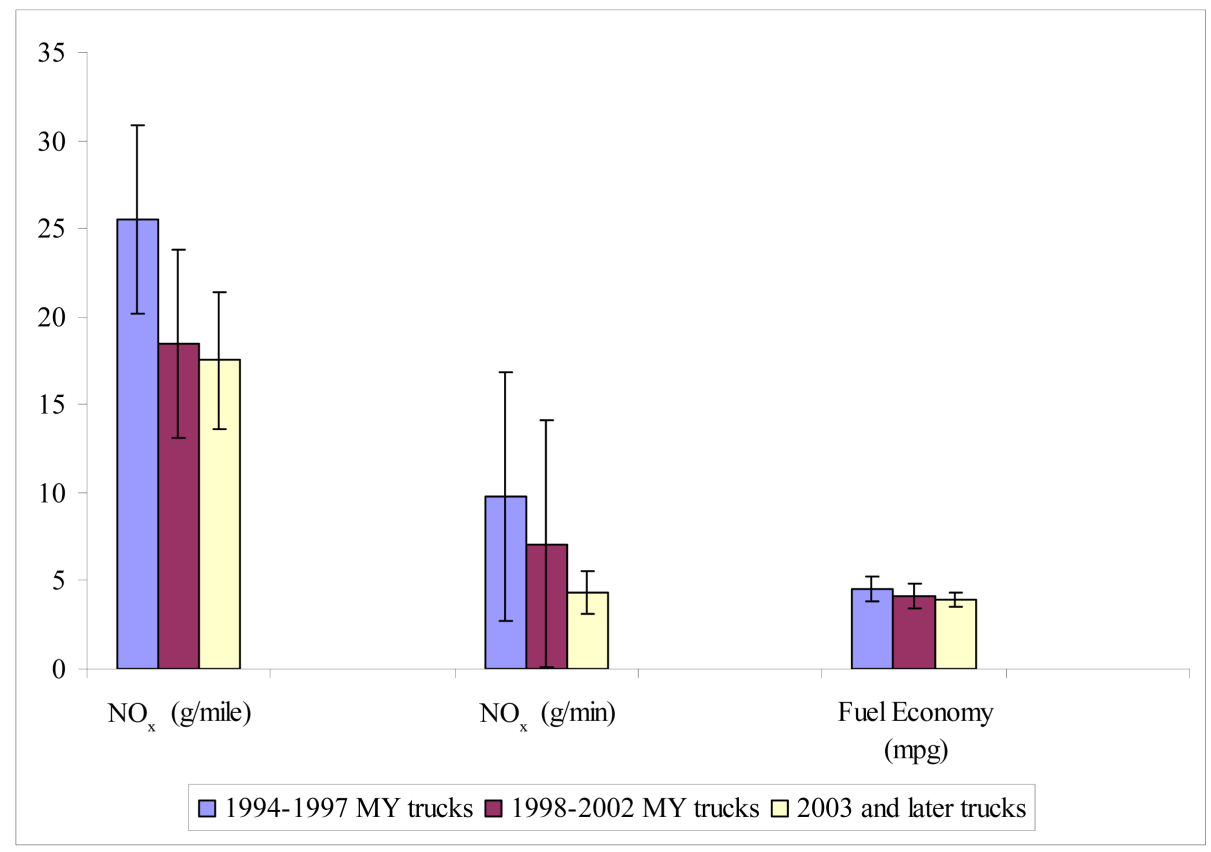

(b)

Figure 6. (a) Comparison of transient cycle emissions of the 2003-2005 MY trucks with those of earlier MY trucks; (b) Comparison of high-speed cruise emissions of the 2003-2005 MY trucks with those of earlier MY trucks.

certain times during the cycle, the $\mathrm{NO}_{\mathrm{x}}$ value is allowed to exceed $2.4 \mathrm{~g} / \mathrm{bhp}$-hr. This is unlike NTE certification which puts a cap on the maximum power specific emissions. Hence, based on these standards, the limiting ratio should be $2.4 \mathrm{~g}$ of $\mathrm{NO}_{\mathrm{x}}$ per $525 \mathrm{~g}$ (approximately) of $\mathrm{CO}_{2}$; hence the ratio for certification should be 0.0046 . This was comparable to the 2003-2005 MY truck average of 0.0051. From the earlier study by Ramamurthy and Clark [7], the average $\mathrm{NO}_{\mathrm{x}} / \mathrm{CO}_{2}$ for the older MY trucks was 0.01 . In another similar study conducted by Khan and Clark [36], the average $\mathrm{NO}_{\mathrm{x}} / \mathrm{CO}_{2}$ ratio for the E-55/59 trucks from 1991-2004 MY tested on the transient 


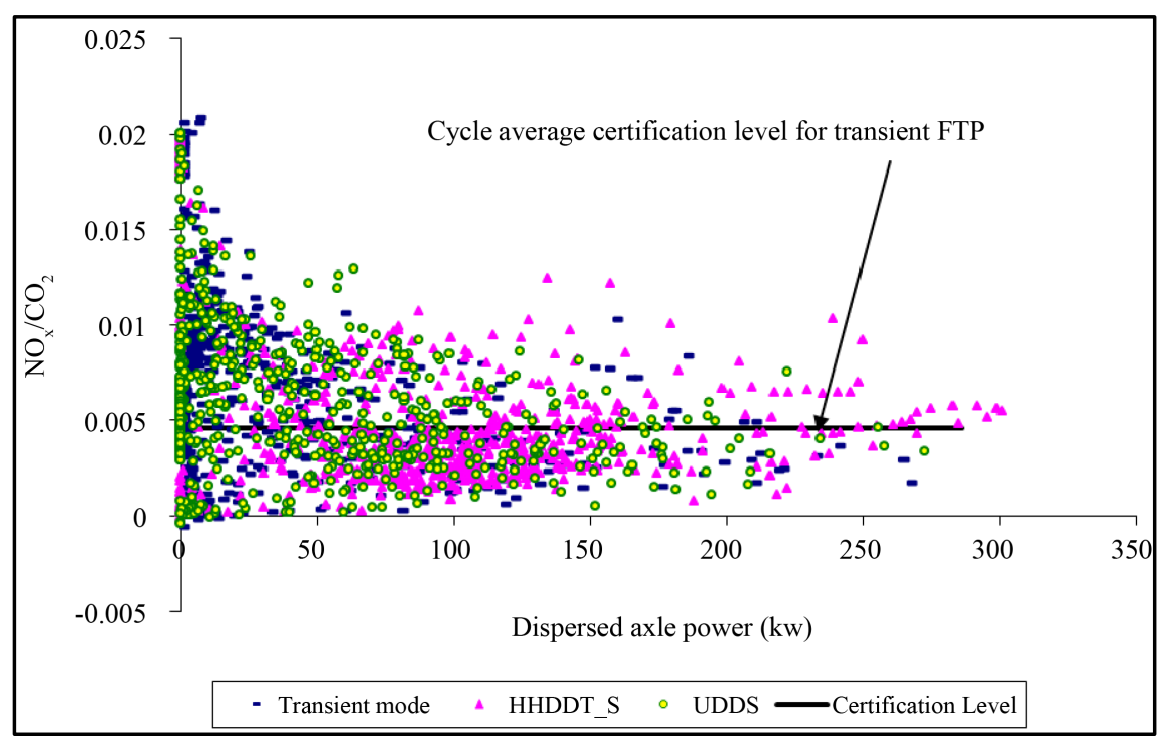

Figure 7. $\mathrm{NO}_{\mathrm{x}} / \mathrm{CO}_{2}$ vs. dispersed axle power for CRC-34 (MY 2004) loaded at 56,000 lbs.

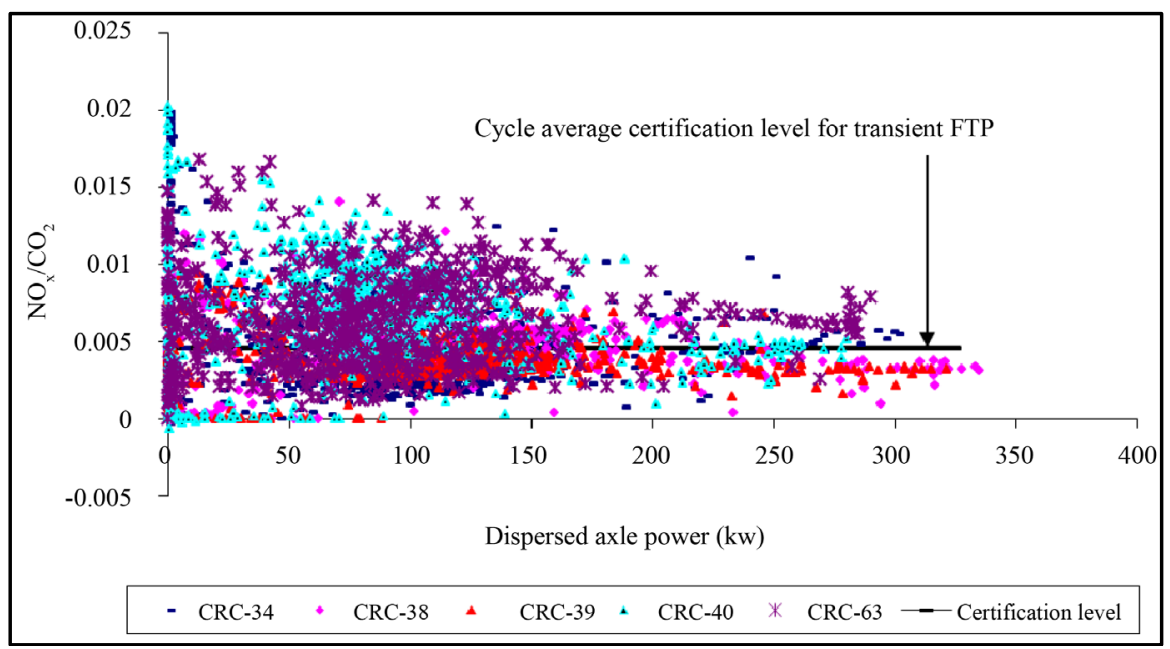

Figure 8. $\mathrm{NO}_{\mathrm{x}} / \mathrm{CO}_{2}$ vs. dispersed axle power for five 2003-2005 MY trucks loaded at 56,000 lb and tested on the HHDDT_S.

mode was found to be 0.0089 .

\section{Conclusion}

The main objective of this paper is to provide the research community with power specific $\mathrm{CO}_{2}$ and $\mathrm{NO}_{\mathrm{x}}$ emissions levels for the 2003-2005 MY heavy-duty vehicles. Five different trucks were tested on the UDDS and the transient and high-speed cruise modes of the HHDDT. For all the cycles, the emission rates increased with increasing power. However, the linear dependence of mass rate on power was different for $\mathrm{CO}_{2}$ and $\mathrm{NO}_{\mathrm{x}}$. The $\mathrm{CO}_{2}$ mass rate was correlated well with the power $\left(\mathrm{R}^{2}=0.85\right)$, but the $\mathrm{R}^{2}$ value for correlation of $\mathrm{NO}_{\mathrm{x}}$ with power $\left(R^{2}=0.50\right)$ was significantly lower than the $R^{2}$ value for correlation for earlier MY vehicles $\left(R^{2}=0.85\right.$ from the study by Ramamurthy and Clark [7]). This is attributed to the complex emission controls employed by the modern trucks. For example, with multiple injections or cooled EGR in use, $\mathrm{NO}_{\mathrm{x}}$ emissions are governed less simply by injection timing. The cycle-to-cycle variation of the emission rates was studied and second-degree polynomial equations were developed for each cycle. The effects of three test weights on the emission rates were presented. The linear fits for the three weights had similar slopes and intercepts. This suggested that the test weight 
does not significantly affect the $\mathrm{CO}_{2}$ and $\mathrm{NO}_{\mathrm{x}}$ emissions rate against power. $\mathrm{NO}_{\mathrm{x}} / \mathrm{CO}_{2}$ ratio was computed for the 2003-2005 MY trucks for all the cycles. The average $\mathrm{NO}_{\mathrm{x}} / \mathrm{CO}_{2}$ ratio of 0.0051 was in a good agreement with the current certification level of 0.0046 . The time rate $(\mathrm{g} / \mathrm{min})$ and the distance specific $(\mathrm{g} / \mathrm{mile}) \mathrm{NO}_{\mathrm{x}}$ for transient and high-speed cruise modes were compared with those from the earlier MY trucks (1994-2002). When compared to the 1994-1998 MY trucks, the 2003-2005 MY trucks showed a decrease of about 40\% in distance specific $\mathrm{NO}_{\mathrm{x}}$ emissions in both the transient and high-speed cruise. The drop is in conjunction with the drop in the acceptable levels for certification.

\section{Acknowledgements}

The truck emissions data were obtained from the E-55/59 program (see reference [8]) sponsored by the Coordinating Research Council, CARB, USEPA, Department of Energy Office of Freedom CAR and Vehicle Technologies, National Renewable Energy Laboratory, South Coast Air Quality Management District and the Engine Manufacturers Association.

\section{References}

[1] US Bureau of the Census (2002) 2002 Vehicle Inventory and Use Survey. http://www1.eere.energy.gov/vehiclesandfuels/facts/2005/fcvt fotw363.html

[2] Kirchstetter, W.T., Harley, A.R., Kreisberg, N.M., Stolzenburg, M.R. and Hering, S.V. (1999) On-Road Measurement of Fine Particle and Nitrogen Oxide Emissions from Light and Heavy-Duty Motor Vehicles. Atmospheric Environment, 33, 2955-2968. http://dx.doi.org/10.1016/S1352-2310(99)00089-8

[3] Yanowitz, J., Allenman, T.L., Ryan, L.B., McCormick, R.L. and Graboski, M.S. (2000) Chassis Dynamometer Study of Emissions from 21 In-Use Heavy-Duty Diesel Vehicles. Environmental Science and Technology, 33, 209-216. http://dx.doi.org/10.1021/es980458p

[4] Clark, N.N., Gautam, M., Wayne, W.S., Long, T.R., Thompson, G.J., Lyons, D.W. and Maldonado, H. (2006) Regulated Emissions Data from All Four Phases of the E-55/59 Program. 16th CRC On-Road Vehicle Emissions Workshop, San Diego, March 2006.

[5] Office of the Federal Register, National Archives and Records Administration (1998) Notice of Filing a Consent Decree under the Clean Air Act. Federal Register, 63, No. 212.

[6] Emission Standards: USA: Heavy-Duty Truck and Bus Engines (2006). www.dieselnet.com, www.dieselnet.com/standards/us/hd.html

[7] Ramamurthy, R. and Clark, N.N. (1999) Atmospheric Emissions Inventory Data for Heavy-Duty Vehicles. Environmental Science and Technology, 33, 55-62. http://dx.doi.org/10.1021/es980692f

[8] Clark, N.N., Gautam, M., Wayne, W.S., Lyons, D.W. and Thompson, G. (2007) Heavy-Duty Vehicle Chassis Dynamometer Testing for Emissions Inventory. CRC Report No. E 55/59, Coordinating Research Council, Inc., Alpharetta.

[9] Clark, N.N., Gautam, M., Wayne, W.S., Lyons, D.W. and Thompson, G. (2004) California Heavy Heavy-Duty Diesel Truck Emissions Characterization for Project E-55/59-Phase 1.5, Final Report.

[10] Clark, N.N., Gautam, M., Bata, R.M., Loth, J.L., Palmer, G.M., Wang, W.G. and Lyons, D.W. (1995) Design and Operation of a New Transportable Emissions Laboratory for Emissions Testing of Heavy-Duty Trucks and Buses. International Journal of Vehicle Design, Heavy Vehicle Systems, Special Series, 308-322.

[11] Ferguson, D.H., Gautam, M., Wang, W.G., Clark, N.N., Lyons, D.W., Bata, R.M., Palmer, G.M. and Katragadda, S. (1992) Exhaust Emissions from In-Use Heavy-Duty Vehicles Tested on a Transportable Transient Chassis Dynamometer. SAE Paper 922436.

[12] Clark, N.N., Lyons, D.W., Gautam, M., Bata, R.M., Wang, W.G., Norton, P. and Chandler, K. (1997) Natural Gas and Diesel Transit Bus Emissions Review and Recent Data. Proceedings of the SAE Truck and Bus Conference, Cleveland, 17-19 November 1997, SAE Paper 973203.

[13] Clark, N.N., Lyons, D.W., Gautam, M., Bata, R.M., Wang, W.G., Norton, P. and Chandler, K. (1997) Natural Gas and Diesel Transit Bus Emissions Review and Recent Data. SAE Technical Paper 973203.

[14] Salem, M.I., Mucino, V.H. and Gautam, M. (1999) Speed Dependent Rolling Resistance Evaluation of a Twin Roller Chassis Dynamometer for Heavy-Duty Vehicles. International Journal of Computer Applications in Technology, 12, 349-357. http://dx.doi.org/10.1504/IJCAT.1999.000218

[15] Jacobs, T., Assanis, D. and Filipi, Z. (2003) The Impact of Exhaust Gas Recirculation on the Performance and Emissions of a Heavy-Duty Diesel Engine. SAE Technical Paper 2003-01-1068. 
[16] Baert, R.G., Beckman, D.E. and Veen, A. (1999) Efficient EGR Technology for Future Heavy-Duty Diesel Engine Emission Targets. SAE Technical Paper 1999-01-0837.

[17] Kohketsu, S. (1996) Exhaust Gas Recirculation in Turbocharged Diesel Engines. Proceedings of JASE Convention, Paper No. 9638266.

[18] Hiereth, U., Gartner, M., Lohle, C. and Pfendec, H. (1997) Investigation of Cooling and Recirculating Exhaust Gases in Heavy-Duty Truck Engines, Development of an Exhaust Gas Cooler. Proceedings of the 18th International Vienna Motor Symposium Series, 306, 321-340.

[19] Yamada, T., Ikeya, N. and Kondoh, N. (1998) New EGR System for Heavy-Duty Diesel Engines. SAE Technical Paper 980775.

[20] McKain, D.L., Clark, N.N., Daniel, T.I. and Hoppie, J.A. (1998) Chassis Test Cycle Development for Engine Test Compliance on Heavy-Duty Vehicles. SAE Technical Paper 980407.

[21] Gautam, M., Clark, N.N., Riddle, W., Nine, R., Wayne, W.S., Maldonado, H., Agarwal, A. and Carlock, M. (2002) Development and Initial Use of Heavy-Duty Diesel Truck Test Schedule for Emissions Characterization. SAE Technical Paper 2002-01-1753.

[22] Clark, N.N., Gautam, M., Wayne, W.S., Riddle, W., Nine, R.D., Lyons, D.W. and Xu, S. (2004) Examination of Heavy Heavy-Duty Diesel Truck Chassis Dynamometer Schedule. SAE Technical Paper 2004-01-2904.

[23] Messer, J.T., Clark, N.N. and Lyons, D.W. (1995) Measurement Delays and Modal Analysis for a Heavy-Duty Transportable Emissions Testing Laboratory. SAE Paper 950218.

[24] Hawley, J.G., Brace, C.J., Cox, A., Ketcher, D. and Stark, R. (2003) Influence of Time-Alignment on the Calculation of Mass Emissions on a Chassis Dynamometer. SAE Paper 2003-01-0395.

[25] Hawley, J.G., Bannister, C.D., Brace, C.J., Cox, A., Ketcher, D. and Stark, R. (2004) Further Investigations on TimeAlignment. SAE Paper 2004-01-1441.

[26] Aravelli, A. (2003) Real Time Measurement of Oxides of Nitrogen from Heavy-Duty Diesel Engines. Master’s Thesis, Department of Mechanical and Aerospace Engineering, West Virginia University, Morgantown.

[27] Madireddy, M.R. and Clark, N.N. (2006) Sequential Inversion Technique and Differential Coefficients Approach for Accurate Instantaneous Measurement. International Journal of Engine Research, 7, 437-446. http://dx.doi.org/10.1243/14680874JER00406

[28] Madireddy, R.M. (2008) Methods for Reconstruction of Transient Emissions from Heavy-Duty Vehicles. Doctoral Dissertation, Department of Mechanical and Aerospace Engineering, West Virginia University, Morgantown.

[29] Ramamurthy, R. (1999) Heavy-Duty Emissions Inventory and Prediction. Master’s Thesis, Department of Mechanical and Aerospace Engineering, West Virginia University, Morgantown.

[30] Ramamurthy, R., Clark, N.N., Lyons, D.W. and Atkinson, C.M. (1998) Models for Predicting Transient Heavy-Duty Vehicle Emissions. SAE Technical Paper 982652.

[31] Madireddy, R.M. and Clark, N.N. (2009) Attempts to Enhance the Differential Coefficients Approach for Reconstruction of Transient Emissions from Heavy-Duty Vehicles. International Journal of Engine Research, 10, 65-70.

[32] Clark, N.N., Khan, A.S., Thompson, G.J., Wayne, S.W., Gautam, M. and Lyons, D.W. (2005) Idle Emissions from Heavy-Duty Diesel Vehicles. Proceedings of the Diesel Engine Emissions Reduction (DEER) Conference, Chicago, 21-25 August 2005

[33] Filipi, Z., Wang, Y. and Assanis, D.N. (2001) Effect of Variable Geometry Turbine on Diesel Engine and Vehicle System Transient Response. SAE Paper 2001-01-1247.

[34] Watson, N. and Banisoleiman, K. (1988) A Variable Geometry Turbocharger Control System for High Output Diesel Engines. SAE Paper 880118.

[35] Hawley, J.G., Wallace, F.J., Cox, A., Horrocks, R.W. and Bird, G.L. (1999) Reduction of Steady State $\mathrm{NO}_{x}$ Levels from an Automotive Diesel Engine Using Optimized VGT/EGR Schedules. SAE Paper 1999-01-0835.

[36] Khan, A.S., Clark, N.N., Thompson, G.J., Wayne, W.S., Gautam, M., Lyons, D.W. and Hawelti, D. (2006) Idle Emissions from Heavy-Duty Diesel Vehicles-Review and Recent Data. Journal of Air \& Waste Management Association, 56, 1404-1419. http://dx.doi.org/10.1080/10473289.2006.10464551 